\title{
CHANGING PATTERNS OF HOSPITAL LIABILITY IN CANADA
}

\author{
ALLEN M. LINDEN*
}

\section{INTRODUCTION}

Whenever social and economic conditions transmogrify institutions, the law must be transformed to reflect these developments. The evolution of hospital liability in the last generation illustrates this ability of the common law to shed its former skin and to be reborn. Today more than 20,000 doctors perform surgical operations and direct the treatment of a nation of 20 million people in over one thousand hospitals throughout Canada. Recent institutional reforms, altering patterns of specialization and emerging techniques of modern medicine have demanded new legal concepts for their control, since the simplistic attitudes of a bygone era were no longer adequately serving our society. Consequently, the theories for imposing civil liability upon hospitals have undergone drastic surgery and the courts are displacing the obsolete ones. The standard of care required of medical practitioners has been transmuted as well, but that fascinating tale will be left to others. ${ }^{1}$ In this paper attention will be paid rather to the vicarious liability of hospitals for their burgeoning staffs. It will avoid the vicarious liability of hospitals for their janitorial and other non-professional staff ${ }^{2}$ and will concentrate on liability for the negligence of professional personnel both in and out of the operating room.

Critics have attacked the present law from several angles. Some decry the unreality of seeking a "negligent" wrongdoer upon whom civil liability is to be imposed because of the difficulty of proving "unprovable fault," the needless expense involved in resolving these disputes, and the fear produced in doctors' hearts by potential malpractice suits that hinders medical treatment. ${ }^{3}$ Others, particularly plaintiffs' lawyers, attack the medical profession for what it terms a "conspiracy of silence" and charge that doctors improperly shield their colleagues from tort liability, even when they may be negligent. ${ }^{4}$ Without doubt, mishaps in the operating room and elsewhere in the hospital may sometimes remain undetected and, if discovered, may not always be

- B.A., LL.M., Osgoode Hall Law School, visiting Professor of Law, University of California, Berkeley (1966-1967).

1 See Generally, Nathan, Medical Negligence (1952): Meredith Malpractice Liability of Doctors and Hospitals (1956); McCoid. The Care Required of Medical Practitioners (1959), 12 Vand. L. Rev. 549; Louisell \& Willams, Trial of Malpractice Cases (1960) Sherman, The Standard of Care in Malpractice Cases (1966), 4 Osgoode H.L. J. 222. See the spectacular concurring opinion of Justice Tobriner urging strict liability for doctors in Clark v. Gibbons, (1967) Cal.

2 On this topic. See Special Lectures of the Law Society of Upper Canada on Medical Liability (1963), at 203. See also for an example of such a case Lepine v. University Hospital Bd. (1965), 54 D.L.R. (2) 340 (Alta. C.A.); Liability for an epileptic who leaped out of fourth floor window because of insufficient supervision.

3 Ehrenzweig. Compulsory "Hospital-Accident" Insurance: A Needed First Step Toward the Displacement of Liability for "Medical Malpractice" (1964), 31 U. Chi. L. Rev. 279; Polsky, The Malpractice Dilemma: A Cure for Frustration (1957), 30 Temp. L.Q. 359.

4 Belli, Ready for the Plaintiff (1957), 30 Temp. L.Q. 408, reprinted from a book by the same name, (1956). 
adjudicated upon. $^{s}$ The courts seem to have recognized these problems and have begun to adjust tort doctrine to improve the plight of the victims. A complete solution may not be possible via tort law alone, but the laws of torts can help to fill the reparation gap. Ultimately, a legislative remedy may have to be enacted and some have been proposed already. ${ }^{6}$ No easy answer, however, will be able to resolve the conflict between the desire to protect patients and the necessity for permitting doctors and hospitals the maximum of freedom in their role of treating the sick. Adding to the complexity of the problem to be resolved are internal control problems and issues of autonomy between hospital administrators, nursing staff, medical personnel and other technicians.

A fragmentary beginning can be detected in the recent decisions concerning the tort liability of hospitals. Recognizing the complicated tasks that employees perform today, the courts have jettisoned the notion that one could not be responsible vicariously for the conduct of his employees unless he could control the manner of doing their work. ${ }^{\top}$ First the "right to control test" and now the "organization test" have filled the breach. ${ }^{8}$ Reflecting the changing nature of hospital organization and operating room techniques, the courts are abandoning earlier theories of liability and placing the burden of responsibility upon the hospitals, where it is felt it can be more effectively carried. This paper will begin by tracing the demise of the theory that there could be no vicarious liability for professional negligence, it will then consider the special problem of liability for negligence in the operating room, and then will offer some conclusions. Throughout the paper consideration will be given to policy factors in addition to doctrinal matters.

\section{VICARIOUS LIABILITY OF HOSPITALS FOR PROFESSIONAL STAFF}

Until 1942 it was thought that an English hospital was not vicariously liable for the negligence of a doctor or for a nurse performing "professional" rather than "ministerial" duties on the basis of Hillyer v. St. Bartholomew's Hospital. ${ }^{8}$ This position rested upon the notion that no master-servant relationship can exist unless the master could control the manner in which work is to be performed. Since the hospital administrators, who frequently lacked professional training, did not normally purport to supervise professional personnel in the method of conducting their medical practice, there was no control, and, accordingly, no vicarious liability. The main tort duty under which a hospital laboured, apparently, was the need to select its personnel carefully. ${ }^{10}$

5 The Canadian Medical Protective Association, which insures over 15,000 doctors more than $75 \%$ of the doctors in Canada, reports that only 49 writs were issued in 1965, a remarkably minute number. Of the 17 of these that went to trial 13 were dismissed and 4 were decided for the claimant (three of the latter group were under appeal however).

6 See Ante, n. 3.

7 See Fleming, The Law of Torts, (3d ed. 1965), at 339.

8 Ibid. The latter has now been adopted by the Supreme Court of Canada in another context, See Co-operator's Insurance Co. v. Kearney (1965), 48 D.L.R. (2d) 1 (Justice Spence).

9 [1909] 2 K.B. 820 (per Kennedy, L. J.)

10 See Goodhart, Hospitals and Trained Nurses (1938), 54 L.Q.R. 553, at 553 for a critique of the law. See also MacLeod, The Liability of a Hospital for the Negligence of a Nurse (1940), 18 Can. Bar Rev. 776. 
In recent years, this principle has been swept away. In Gold v. Essex County Council" the English Court of Appeal discarded the administrative-professional dichotomy as "unworkable and contrary to plain sense,"12 and held a hospital liable for a radiology technician who negligently administered some Grenz ray treatments. Lord Goddard compared the position of the technician to that of a nurse, and suggested that merely because an employee had some special skill did not mean that he could never be a servant so as to make his employer vicariously liable. ${ }^{13}$ Planting the seed for future growth, Lord Greene, the Master of the Rolls, based his decision on a direct obligation to nurse rather than upon the obligation to supply a nurse. ${ }^{14}$ This notion resembles a contractual duty, but apparently no consideration would be necessary for it to apply. After what appears to be a short step backward, ${ }^{15}$ this concept of a non-delegable duty owed directly by the hospital to its patient was reiterated in Cassidy v. Minister of Health, ${ }^{16}$ where a hospital was held liable for the negligence of one of its house surgeons, who "were employed like nurses as part of the permanent staff of the hospital."17 Relying on the new personal duty of care, Lord Justice Denning went much further: ${ }^{18}$

\begin{abstract}
... In my opinion authorities who run a hospital, be they local authorities, government boards, or any other corporation, are in law under the selfsame duty as the humblest doctor; whenever they accept a patient for treatment, they must use reasonable care and skill to cure him of his ailment. The hospital authorities cannot, of course, do it by themselves: they have no ears to listen through the stethoscope, and no hands to hold the surgeon's knife. They must do it by the staff which they employ; and if their staff are negligent in giving the treatment, they are just as liable for that negligence as is anyone else who employs others to do his duties for him. What possible difference in law, I ask, can there be between hospital authorities who accept a patient for treatment, and railway or shipping authorities who accept a passenger for carriage? None whatever. Once they undertake the task, they come under a duty to use care in the doing of it, and that is so whether they do it for reward or not.

.. . Relieved thus of Hillyer's case, this court is free to consider the question on principle: and this leads inexorably to the result that, when hospital authorities undertake to treat a patient, and themselves select and appoint and employ the professional men and women who are to give the treatment, they are responsible for the negligence of those persons in failing to give proper treatment, no matter whether they are doctors, surgeons, nurses, or anyone else. Once hospital authorities are held responsible for the nurses and radiographers, as they have been in Gold's case, I can see no possible reason why they should not also be responsible for the house surgeons and resident medical officers on their permanent staff.
\end{abstract}

This principle was reaffirmed in Roe v. Ministry of Health, ${ }^{10}$ where a hospital was held responsible for the negligence of a part-time anaesthetist who injected defective Nupercaine, causing the plaintiff to become paraplegic. Lord Justice Somervell regarded the anaesthetist "as part of the permanent staff and, therefore, in the same position as the orthopaedic surgeon in Cassidy's case."20 Lord Justice Morris agreed that the hospital

11 [1942] 2 K.B. 293; See also Logan v. Waitaki Hospital Board, [1935] N.Z.L.R. 385 (nurse administering heat ray-distinction between professional-ministerial rejected). 12 Ibid, (Lord Greene, M. R.)

13 Ibid.

13 Ibid.

14 Ibid.

liable because of lack of requisite control, though interne did). This case criticized by Nathan, ante, $n$. 1, at 141

16 [1951] 2 K.B. 343.

17 Id., at 351 (Somervell, L. J.)

18 Ibid.

19 [1954] 2 Q.B. 66 (C.A.).

20 Id., at 79. 
assumed an obligation to anaesthetize the plaintiff and "the anaesthetists were members of the 'organization' of the hospital: they were members of the staff engaged by the hospital to do what the hospital itself was undertaking to do." He then suggested that this was a case of respondeat superior, despite the highly skilled nature of the work. ${ }^{21}$

The English position, therefore, was drastically transformed in response to altered social and economic conditions. Judicial reluctance to burden hospitals with civil liability, because they were often private charitable institutions struggling along with meagre funds, has yielded to a new willingness to reach into the deep pocket of the Ministry of Health, which has largely taken over the operation of most hospitals. The theory of direct obligation has been merely a technique utilized to accomplish this transition. ${ }^{22}$

At least one strand of the abandoned theory was retained, however; where a patient himself hires his own doctor, the hospital will not be responsible for that doctor's negligence, since the latter is not the servant of the hospital, but is truly an independent contractor. ${ }^{23}$ Since the hospital has less opportunity to control private medical practice, since the usual economic sanctions available to an employer are absent, and since the independent medical practitioner is not really a part of the hospital organization placed at the service of its patients, this result is understandable. The present law in England, then, is that the negligence of any of the hospital employees, whether skilled or not, may render it liable to its patients. ${ }^{24}$ However, those who are not employed by the hospital cannot render it liable. ${ }^{25}$ The theoretical basis of this liability appears to be a sort of contractual one in which the hospital directly undertakes a duty to supply certain services to its patients, which has eclipsed the older vicarious liability theory.

The Canadian decisions, unlike the English ones, are still in a confused state. Our courts proudly proclaimed their independence from the administrative-professional dichotomy of Hillyer even prior to Gold, ${ }^{20}$ and unwittingly enunciated the direct duty rule; ${ }^{27}$ nevertheless, in practice they always managed to find that the offending conduct was of an administrative nature requiring no professional skill. ${ }^{28}$ This theory did not win early acceptance in Alberta, however, where an X-ray technician rendered his hospital responsible upon the Hillyer principle, and where in a dictum, Justice McGillivray criticised Lavere. ${ }^{20}$

Although the direct-obligation-to-nurse theory was articulated quite early in Canada, there seems to be no decision involving a fully qualified doctor or nurse which rests exclusively on this principle. ${ }^{30}$ In Nyberg v.

21 Id., at 91.

22 Denning. The Changing Law (1953), at 29; See also Cassidy, ante n. 16, at 361.

23 Cassidy, ante, n. 16.

24 See N.than, ante n. 1, at 132; Higgins v. N. W. Metropolitan Hospital Board, [1954] 1 W.L.R. $411,422$.

25 Fleming, ante, n. 7, at 343. See also Cassidy, ante, n. 16.

26 See Sisters of St. Joseph v. Fleming, [1938] 2 D.L.R. 417 (S.C.C.), at $422,431$.

27 See Lavere v. Smith's Falls Hospital (1915), 35 O.L.R. 98 (C.A.), at 105, 114 (hot bricks used to keep patient's feet warm burned him).

28 Id., at 118. The nurse "was engaged in a matter of routine nursing, doing for the defendants part of the very service which they had contracted to render the plaintiff." (per Justice Latchford); at 107, "The duties of the nurse, when the default occurred in the present case, were not to assist the surgeon in matters of professional skill ... but to . . perform domestic duties..." (per Justice Riddell).

29 Abel v. Cooke, [1938] 1 D.L.R. 170, $181^{\circ}$ (Alta. C.A.).

so There is one case where an interne imposed liability upnn his hospital, but the holding is obscure. See Vancouver General Hospital v. Fraser, [1952] 2 S.C.R. 36. 
Provost Municipal Hospital, ${ }^{31}$ for example, a hospital was held liable for the negligence of one of its nurses who scalded the plaintiff's leg with a hot water bottle. The Chief Justice of Canada, Justice Anglin, after stating that "the obligation undertaken by the hospital was not merely to supply properly qualified nurses, but to nurse the plaintiff," proceeded to indicate that this was "a matter of ministerial ward duty, if not mere routine," in any event. ${ }^{32}$ Two of the Justices dissented, preferring to follow the Hillyer decision rather than Lavere.

In the Sisters of St. Joseph v. Fleming case ${ }^{33}$ the court criticised the Hillyer ministerial-professional dichotomy as "difficult of practical application," purported to overrule it, and then decided that a heat treatment was a matter of routine for which the hospital was liable. ${ }^{34}$ Other cases can be found in which a hospital has been held civilly liable for administrative acts of its professional staff ${ }^{35}$ and authority exists for the view that a hospital is not to be liable for the negligence of a nurse acting in her professional capacity. ${ }^{30}$

Following Gold the Canadian courts seem to have altered their approach in order to reflect the transformation of English law. In Vancouver General Hospital v. Fraser ${ }^{37}$ a hospital was held liable for the negligence of one of its internes, who failed to read an X-ray properly. The Supreme Court of Canada espoused a theory of a direct obligation to afford both nursing and medical attention, but failed to discard the Hillyer decision once and for all. More direct was the attack on Hillyer made by Justice Doull, in Petite v. McLeod. ${ }^{38}$ Relying on the Fleming case,$^{39}$ he said that there was no difference between professional and non-professional acts. ${ }^{40}$ Unfortunately, the holding in Fleming did not go that far; it seemed willing to countenance future examination of this approach in determining whether a master-servant relationship existed, and actually invoked the Hillyer test unconsciously during its deliberations. In any event, all of this discussion was merely dicta in Petite v. McLeod, since the hospital was exonerated, because there was insufficient evidence that a swab had been left in the patient and because the doctor involved was not on the hospital staff.

The problem of whether a hospital is liable for its permanent staff of doctors and nurses, therefore, is still unresolved in Canada. In England a hospital is now clearly responsible for all these people, whether they are skilled or whether they are not and even if they are not controlled in the way they do their work. There is no Canadian case, how-

\footnotetext{
31 [1927] S.C.R. 226 (S.C.C.) (4 to 2 decision).

32 Id., at 232 (Anglin, C. J. C.).

33 [1938] 2 D.L.R. 417 (S.C.C.)

34 See McLeod article ante $n$. 10, at 789 .

35 See also Barker v. Lockhart, [1940] 3 D.L.R. 42 (N.B.C.A.): silver nitrate into baby's eyes matter of routine only, but in a dictum the court indicated that even if it were not, liability would have been imposed: See also Sinclair v. Victoria Hospital, [1942] D.L.R. 652: liability where child burned by administrative act of nurse (Man. K.B.)

36 Vuchar v. Toronto General Hospital, [1937] 1 D.L.R. 298 (C.A.). At 321, Powell C. J. O. said ". . . the hospital is not responsible to patients for mistakes in medica C. J. O. said in . The hosplan is not resors and nurses. and nurses. of whose professional skill it has so assured itself, . . . but is.. responsible to the patient for the due performance by the members of its professional staff within the hospital of their purely ministerial or administrative duties." On the facts it was held that the nurse who burned the patient was acting in her professional capacity and under the directions of the private doctor involved.

37 [1952] 2 S.C.R. 36

a8 [1955 1 D.L.R. 147 (N.S.H.C.)

30 Ante n. 33.

40 Petite v. McLeod, ante n. 38, at 151-152.
} 
ever, which has held a hospital vicariously liable for a nurse acting in her professional capacity or for a fully-qualified doctor on its staff, although there is a case where a hospital was liable for the negligence of an interne. ${ }^{41}$ The theory has been that there was no control over these people and, consequently, the relation of master and servant could not exist. One hospital has been held responsible for a technician, however. ${ }^{42}$ There has been vocal criticism of Hillyer, but the courts have actually held hospitals liable for the conduct of its staff only where they have found the acts complained of to be routine matters. ${ }^{43}$ On the contrary, there does exist early Canadian authority to the effect that a hospital is not liable vicariously for a graduate doctor on its permanent staff. ${ }^{44}$

Although the theory of the direct obligation of a hospital to nurse a patient has received lip service in Canada, ${ }^{45}$ only in Vancouver General Hospital v. Fraser ${ }^{46}$ did a court appear to apply the theory. But the Supreme Court was not unanimously of this view and no full discussion of the problem and the authorities was undertaken.

The new English theory of direct obligation of the hospital is not yet solidly woven into the fabric of Canadian law, although certain of its threads are visible in the decisions. Before irretrievably adopting the English case, Canadian courts should pause and assess whether the different social conditions in Canada warrant such a development. Too often in the past English decisions have been blindly followed by Canadian Courts, despite dissimilar attitudes and conditions. ${ }^{47}$ The socialization of medicine in England since 1946 has had a considerable impact on the evolution of this branch of the law. ${ }^{48}$ Because civil actions against hospitals are now brought directly against the Ministry of Health which is backed up by limitless public funds, because there may be greater control over doctors by the government in England and because the English may tend to rely more upon their local hospital for care rather than upon their own doctors, this development is understandable. ${ }^{40}$ In Canada, however, although government is introducing itself increasingly into the affairs of hospitals, the medical profession has so far successfully withstood any serious encroachment. Canadians still seek out their own family doctors for care and normally they may be admitted only to the hospital upon whose staff their doctor may be and only at his behest. Since attitudes and practices in Canada differ, the reception of the English rule may not be justified.

There is another reason militating against hospital responsibility for its professional staff. The primary raison d'etre of vicarious liability

41 Vancouver General Hospital v. Fraser, [1952] 2 S.C.R. 36.

42 Abel v. Cooke, [1938] I D.L.R. (Alta. C.A.).

13 Sisters of St. Joseph v. Fleming, [1938] 2 D.L.R. 417. 43' (S.C.C.); Lavere v. Smith's Falls Hospital (1915), 15 O.L.R. 98. 118 (Ont C.A.); Nyberg v. Provost Municipal Hospital, [1927] S.C.R. 226, 212

44 See Vuchar, ante n. 36, at 302 (Powell, C. J. O.), and Lavere, ante n. 27, at 121-122 (Kelly, J.).

15 Lavere, ante n. 27, at 105, 114: Abel v. Cooke, ante n. 28 (McGillivray, J.): Nyberg v. Provost, ante, n. 43, at 232 (Anglin, C.J. C.).

to Ante, n. 37, at 64 .

47 One remarkable example where a court openly acknowledged differences of conditions and departed from English law was Fleming v. Atkinson (1956), 5 D.L.R. 309, 323 (Roach, J. A.) affirmed [1959] S.C.R. 513.

18 See Denning, The Changing Law (19;3), at 29, and Cassidy, ante, n. 16, at 361.

49 See Fleming, Developments in the English Law of Medical Liability (1959), 12 Vanderbilt $L$ R. 633, at 638 . The limitation period in a malpractice case against a doctor may be akin to that of a government officlal in England: See Razzle v. Snowball, [1954] 3 All E.R. 429 (C.A.). 
was to ensure the satisfaction of any judgments secured against employees, who were often judgment-proof. ${ }^{\text {so }}$ This need for vicarious liability evaporates, however, if the employees in question are covered by liability insurance that pays any judgments secured against them. Since virtually all Canadian doctors carry malpractice insurance, any successful claimants will be recompensed without the necessity of holding hospitals responsible as well. The courts may wish to distinguish between nurses, technicians and internes who may be uninsured, on the one hand, and doctors, on the other hand, who are almost certain to carry malpractice insurance. Moreover, the former group may be subjected to greater control by the hospital than the doctors on their staff.

Another potentially evil effect of the English rule is to encourage multiplicity and circuity of actions. Because Lister v. Romford Ice ${ }^{51}$ permits a master to indemnify himself against a servant for whose negligence he has been held vicariously liable, actions against hospitals may be followed by actions against doctors by those hospitals, with its attendant waste of time, effort and expense. If protection can be afforded to plaintiffs without the encouragement of this spectacle, which is in reality only a subrogation battle between the hospital's insurer and the doctor's, it might well be avoided. Where evidentiary problems becloud the issue, as in the case of operating room mishaps, ${ }^{32}$ there may be valid reasons to make the hospital at least initially liable, since there is a risk that the claimant with a meritorious claim may fail for lack of proof. This result, however, would not be indicated in cases where there is evidence of the negligence of an individual professional person.

Nevertheless, notwithstanding the different policy arguments that may be advanced in opposition to the new principle, the Canadian courts will probably adopt it and hold hospitals liable to their patients for the negligence of its professional staff on the basis of a direct duty of care. They will prefer to do this for several policy reasons. First, because of the dominant position of the modern hospital in selecting the private doctors who will be permitted to utilize their facilities, they may be able to exert some control over them by the promulgation and enforcement of strict rules of conduct to be followed within that hospital. Second, it may be that hospitals will attempt to exert more control over their professional employees and select them with even greater care in order to avoid responsibility. This may rankle some of these professional men, but the interest of safety should probably take precedence over ruffled sensibilities. Third, the simplification of the evidentiary problems that would result might be substantial. No longer would the claimant have to single out the professional employee that caused him injury in order to recover; henceforth, he would be required to demonstrate only that some employee of the hospital probably caused his loss, thus entitling him to reparation. Lastly, the risk of absence of insurance coverage for some employee would be eliminated completely, since virtually all hospitals are covered, and, if they are not, they can satisfy any tort judgments against them. For all of these reasons, the Canadian courts, de-

so See Fleming, ante, n. 7, at 336: Laski, The Basis of Vicarious Liability (1916), 26 Yale L. J. 105; Whllams, Vicarious Liability, 20 Mod. L Rev. 220, at 437. 61 [1957] A. C. 555. See also, Necula v. Ducharme (1963), 38 D.L.R. 736 (Alta. C.A.). 62 See infra in. 
spite the above arguments to the contrary, will likely embrace the direct duty to nurse formula and render our hospitals civilly liable for any negligence of their professional staffs.

\section{VICARIOUS LIABILITY OF HOSPITALS FOR NEGLIGENCE IN THE OPERATING ROOM}

Different problems arise in determining whether the hospital or the surgeon is liable for mishaps which occur in the operating room. In days gone by, the surgeon was held vicariously responsible for all negligence occurring in the operating room, since he was felt to be the "captain-of-the-ship" and in complete control of the entire proceedings. ${ }^{53}$ More recently there has been a retreat from this theory in response to the changing operating room environment.

The issue was treated as one of transfer of servant. ${ }^{54}$ Accordingly, if one of the servants of a hospital had been transferred to some independent contractor or to some other person for whom the hospital was not responsible, it would no longer be responsible for the negligence of that servant. Rather, the other person, to whom the servant had been transferred, would now be vicariously liable for any of his negligence. Why the courts did not decide to hold both the general and the temporary employer jointly responsible is shrouded in mystery. Perhaps it was merely another example of the common law's historic penchant for singling out the "last wrongdoer" to bear the brunt of civil responsibility, which is only now beginning to dissolve. ${ }^{5 s}$ The test that was used generally to determine whether a servant had been transferred was "who has the right at the moment to control the doing of the act?" A newer test, ressembling the older one, is now emerging whereby the court asks, "Who controlled the method of performing the task?" and "Who is entitled to give orders as to how the work should be done?" It should be noted that the onus of establishing that there has been a transfer of servant, rather than a mere transfer of service, rests with the general employer. Lord Wright has stated that there is a "presumption ... against there being such a transfer"s8 and Lord Uthwatt has declared that "the burden of proving the existence of that power of control in the hirer rests on the general employer." This slight obstacle is a sensible one and may be overcome in a proper case by the general employer. Each case, however, depends on its own facts and different factors must be considered by the court in determining who has the right to control at the crucial time. Lord Porter, in the Mersey Docks case ${ }^{60}$ listed the following items to consider: (1) Who is paymaster? (2) Who can dismiss? (3) How long does the alternative service last? What machinery was employed? (5) Was the servant skilled?

This approach was used initially by courts to decide who would be vicariously liable for negligence in the operating room. Relying on the

\footnotetext{
68 See Hillyer v. St. Bartholomew's, [1909] 2 K.B. 820, 828 (Farwell. L.J.).

s4 See Fleming, ante $n$. 7, at 344 .

5s Shields v. Hobbs Mfg., [1962] S.C.R. 716, 34 D.L.R. (2d) 307; Grant v. Sun Shipping, [1948] A.C. 549, 2 All E.R. 238 (H.L.)

50 Donovan v. Laing, [1893] Q.B. 629, 634 (Bowen, L. J.)

57 Mersey Docks, et al v. Coggins, [1947] A.C. 1, 17.

58 Century Insurance Co. v. N.I.R.T.B., [1942] A.C. 509, 1 All E.R. 191

so Mersey Docks case, ante n. 57 .

60 Id. at 17.
} 
captain-of-the-ship doctrine, the courts held the surgeon liable for any negligence in his operating theatre. The theory, as it applied to the negligence of nurses, has been described by Lord Justice Farwell, as follows: ${ }^{\text {o1 }}$

...But although they are such servants for general purposes, they are not so for the purposes of operations and examinations by the medical officers. If and so long as they are bound to obey the orders of the defendants, it may well be that they are their servants, but as soon as the door of the theatre or operating room has closed on them for the purposes of an operation (in which term I include examination by the surgeon) they cease to be under the orders of the defendants, and are at the disposal and under the sole orders of the operating surgeon until the whole operation has been completely finished; the surgeon is for the time being supreme, and the defendants cannot interfere with or gainsay his orders. This is well understood, and is indeed essential to the success of operations; no surgeon would undertake the responsibility of operations if his orders and directions were subject to the control of or interference by the governing body. The nurses and carriers, therefore, assisting at an operation cease for the time being to be the servants of the defendants, inasmuch as they take their orders during that period from the operating surgeon alone, and not from the hospital authorities.

This principle was adopted by the Ontario Court of Appeal where Justice Latchford, in Lavere v. Smith's Falls Hospital, , $^{02}$ indicated that a nurse was, at the time her negligence caused the injury acting as the agent of the physician and not as the servant of the defendants. Justice Kelly stated, "Nurses employed by the hospital, though they may be its servants for general purposes, are not so for the purpose of operations in which they take their orders from the surgeon alone and not from the hospital."0s Liability was imposed upon the hospital, however, in that case since the nurses were performing only a routine duty of keeping the patient warm outside the operating room, and were not acting in obedience to doctor's orders.

The Chief Justice of Canada (Anglin) in Nyberg v. Provost ${ }^{64}$ did not object to the Hillyer case insofar as it held that "nurses on the staff of the hospital while they are actively engaged in assisting a surgeon during an operation ... are so immediately subject to his orders and control that they are for the time being not to be regarded as servants of the hospital authority." ${ }^{\circ 5}$ A similar statement appeared in Vuchar v. Toronto General Hospital ${ }^{68}$ where the Ontario Court of Appeal dismissed an action against a hospital for the acts of a nurse in her professional capacity, under directions of a doctor. Chief Justice Rowell, referring to a concession obviously made by counsel, said, "It is not disputed that the hospital is not liable for the negligent act of the nurse while in the operating room and under the direction and instruction of the surgeon ..." ${ }^{07} \mathrm{Mr}$. Justice Middleton agreed and echoed the Chief Justice of Ontario when he stated, "Here the nurse, while remaining throughout a general employee of the hospital employed by it and paid by it, is lent to the surgeon or physician for his assistance in performing professionally as a nurse the details of surgical and medical treatment prescribed by the surgeon or physician, and, while so doing is not subject to the direction, orders or control of the hospital while exercising

61 Hillyer case, ante n. 53, at 826 .

62 (1915), 35 O.L.R. 98, 117 .

63 Id., at 122 .

of [1927: S.C.R. 226.

65 Id. at 229.

66 [1937] 1 D.L.R. 298.

$67 \mathrm{Id}$, at 322 . 
the professional functions of a nurse." ${ }^{88}$ Even to this day there is no reported decision either in England or Canada that held a hospital liable for the acts of a nurse in the operating room. ${ }^{00}$

More recently, however, a newer theory has evolved which suggests that a hospital will not be liable for a nurse who merely follows particular instructions of the surgeon in the operating room, because there is no negligence on her part, and not because she ceased temporarily to be the servant of the hospital. It is contended that, if ordinary routine required her, or if she were told by the surgeon generally to perform some procedure during the course of an operation and she performed it negligently, the hospital might be liable vicariously for this negligence and not the surgeon. ${ }^{70}$ This reasoning has received the imprimatur of Lord Justice McKinnon who said that "the master will not be liable for the act of his servant if he is only doing, without personal negligence, that which he is directed to do by such third party,"71 and is accepted in South Africa, ${ }^{72}$ New Zealand ${ }^{73}$ and Scotland. ${ }^{74}$ Therefore, the conduct of the supporting staff in the operating theatre would render the hospital liable, unless it were shown that the surgeon ordered the particular act to be done.

This new principle seems to have been adopted by the Nova Scotia Supreme Court in Petite v. McLeod, burden of proving that the liability has shifted from the general employer of the servant, rests upon the general employer and does not depend on the contract between the two employers, but upon the circumstances of this case." If the nurse merely does as she is ordered by the doctor, it is not negligence, but if she negligently carries out "duties which are properly the routine nursing duties, her employer will be responsible." The action was dismissed, however, since no evidence of negligence was found.

The strictest rule of hospital liability had been stated in Logan v. Colchester County Hospital, ${ }^{71}$ where a hospital was held liable when the plaintiff was burned by a hot water bottle applied by a nurse. The court proclaimed that, "a public hospital board is liable for the negligence of even duly qualified nurses employed by it in the performance of all duties other than those done under the direct orders of a physician or surgeon in the course of an operation." Perionowsky v. Freeman, ${ }^{78}$ was an early case where doctors were relieved of liability for the negligence of a nurse in scalding the plaintiff during a hip-bath. They were said to have had no control over the nurses as to appointment or dismissal and, therefore, no relation of master and servant existed. Lord Chief Justice Cockburn stated that they "would not be liable for the negligence of the nurses unless near enough to be aware of it and to prevent it." The hospital was not sued. Based on a

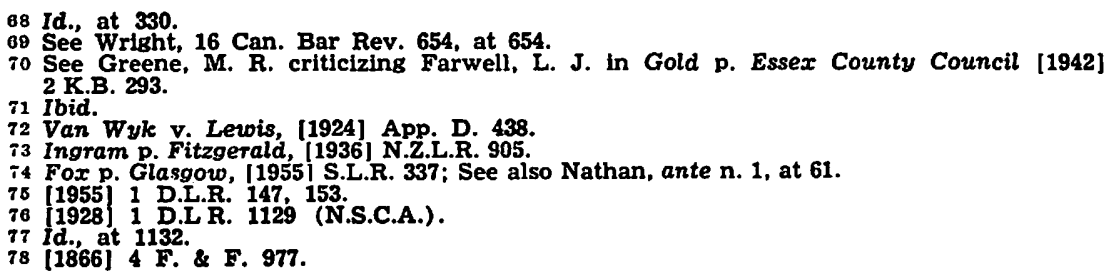


similar theory this, but apparently on opposing facts, liability was to imposed on an anaesthetist where, in his presence, he allowed one assistant to administer pentathol negligently to someone who was already partially anaesthetized. ${ }^{70}$ Further indicative of the complexity and the uncertainty in this area, was the dictum of Justice LeBel in Walker v. $B_{\text {Bedard }}{ }^{80}$ that indicated a doctor would not be liable for the negligence of an anaesthetist that he selected if the latter was properly qualified. This case tends to show, as do the others here discussed, that the "captainof-the-ship" doctrine is being submerged in Canada. They further illustrate that its replacement is still only dimly perceived by the courts. In an article in the Canadian Bar Review, ${ }^{81}$ McLeod concluded that ". . . while it may be just to fasten the employer with liability while he has control of the servant, it would seem to be an unwarranted extension to impose the same liability where the servant is carrying out the instructions of a third party." A slightly different view, however, seems to have been taken by Goodhart in an article in the Law Quarterly Review: ${ }^{82}$

" .. the trained nurse is the servant of the hospital as she is employed to render service and is at all times under the general control of the hospital officials. The fact that she is expected to exercise professional skill and is required to obey the orders of the medical staff does not affect her position. Even in the operating room she remains the servant of the hospital although it is her duty to obey without question all the orders of the surgeon."

He explains the reason for exonerating a hospital when a nurse follows the orders of a doctor exactly as she is directed, is because "in obeying them she is not guilty of negligence even though the doctor has been personally negligent in giving them." ${ }_{83}$ Lord Nathan, in his book Medical Negligence ${ }^{84}$ gives probably the best summary of the English law in these terms:

It is clear in these circumstances that the position is substantially the same whether an operation is in question or not. The hospital nurse is not the servant of the surgeon or doctor under whose temporary control she is and whose instructions it is her duty to obey; and he is not vicariously liable for her negligence in carrying out those instructions or in performing her other duties. Similarly an anaesthetist, although responsible fo rthe choice of the anaesthetic, for the giving of directions as to its preparation and for the general supervision of the activities of the theatre staff, is not liable for the casual acts of negligence of the theatre staff who assist him in the administration of the anaesthetic; he cannot be held liable, for example, for the actions of a nurse who, by careless handling, cracks the ampoule in which the anaesthatic is contained. The hospital authority therefore remains vicariously liable for the negligence of its servants, notwithstanding that they are temporarily under the control or obeying the instructions of some third person who is not its servant, such as the surgeon or a doctor or an anaesthetist. Subject, however, to Goddard, L. J.'s qualification, negligence will not be established against nurses or other subordinates if it is shown that in doing what they did they were following faithfully and carefully the instructions of the surgeon, doctor or anaesthetist-the negligence, if any, will be that of the surgeon, doctor or anaesthatist in giving those instructions.

The American law is just as confused as the English law and is also in a state of flux. The early cases had relieved hospitals of liability for their professional staff, except when performing administrative tasks, on the basis that they could not be controlled in the manner of perfor-

79 Jones v. Manchester Corp. [1952] 2 All F.R. 125.

80 [1945] OW.N. 120. The actions against both the doctor and the anaesthetist were dismissed.

8118 Can. Bar Rev. 776 , at 793

82 Hospitals and Trained Nurses (1938), 54 L.Q.R. 553, at p. 573-4.

83 Id., at 573 .

84 Ante n. 1, at 67. 
mance of the work. ${ }^{85}$ This doctrine is now being abandoned as it has been in England, ${ }^{86}$ and professional personnel often render their hospital employers liable for their conduct. ${ }^{87}$ Moreover, no liability was imposed on hospitals for operating theatre negligence since the head surgeon was felt to be in complete control, and that all servants were transferred to him during an operation. ${ }^{88}$ Sometimes this "captain-of-the-ship" doctrine was carried to such extremes that an obstetrician who was busy working on the mother and had no opportunity to supervise was held liable for an intern who negligently applied silver nitrate to the eyes of the new-born infant. ${ }^{89}$

More recently the American law has been transformed. Modern surgery has grown exceedingly complex and on occasion more than a dozen people may work together on an operating team to do, for example, cardiovascular surgery. Anaesthetists have become specialists in their own right and are no longer subject to the direction of the surgeon but operate more like partners in the operating theatre. Technicians may be in complete control of a heartpump. The law has reflected this development and has refused to hold surgeons liable for the negligence of anaesthetists and other doctors unless they are under the surgeon's direct supervision and control. ${ }^{90}$ Part of the reason for the continued willingness of American courts to hold the head surgeon liable for all operating room mishaps rather than the hospital, may be that government and charitable institutions, which often included hospitals, have been immune from suit in America.91 To protect the patient, liability had to be imposed on a doctor rather than a hospital, since otherwise he might be barred from recovery by one of these immunities. It should be noted that these immunities are succumbing gradually and should stimulate further alterations. ${ }^{92}$

One case that is illustrative of the complicated nature of modern surgery and of judicial response thereto is Thompson v. Lillehei. ${ }^{03}$ An open heart operation was to be performed on a young child to correct a congenital defect. This required the use of "controlled cross-circulation," a special procedure whereby a donor, here the mother, could keep her child alive by furnishing heart and lung facilities to her from an adjoining operating table. Needless to say a large team was necessary to accomplish all of this. Unfortunately, an air embolism got into the mother's vein and damaged her brain due to one doctor's negligence. The

85 Schloendorff v. Society of New York Hospital (1914), 211 N.Y. 125, 105 N.E. 92; Hamburger v. Cornell University (1925), 240 N.Y. 328, 148 N.E. 539; Phillips v. Buffalo General Hospital (1924), 239 N.Y. 188, 146 N.E. 199.

86 Bing v. Thunig (1957), 2 N.Y. (2d) 656, 143 N.E. (2d) 3; See Louisell \& Williams, The Trail of Medical Malpractice Cases (1960), at 488 . It still survives in some states, however. See Benedict v. Bondi (1956). 384 Pa. 574, 122 A. (2d) 209; Swigert v. Ortonville (1956), 246 Minn. 339, 75 N.W. (2d) 217 .

87 Garfield Memorial Hospital v. Monshall 204 F. (2d) (psychiatrist): Brown v. Moore, 247 F. (2d) 711 (Interne): Bougeois v. Dade County (1952), 99 So. (2d) 575 (Fla.); Moeller v. Hauser (1952), 237 Minn. 368,54 N.W. (2d) 639 '(resident).

88 See St. Paul v. St. Joseph's Hospital (1942), 212 Minn. 518, 4 N.W. (2d) 637. Anderhold v. Bishop (1925), 94 Okla. 203, 221 Pac. 752.

80 McConnell v. Williams (1949), 361 Pa. 355, 65 A. (2d) 343; See also Rockwell v. Stone (1960), 175 A. (2d) 54 .

80 See Louisell \& Williams, ante n. 86, at 489; McCoid. The Care Required of Medical Practitioners (1959), 12 Vand. L. Rev. 549, at p. 598

91 For a complete discussion of this, see Lcuisell \& Williams, ante $n .86$, c. XVII, at 511. See also Muscopf v. Corning Hospital District, 55 Cal. (2d) 211, 359 P. (2d) 457, where the Bovernmental immunity was abolished by the court. However it was reintroduced soon after by the legislature. See Nellis, Retroactivity of the 1963 California Governmental Tort Law: A Legislative Triumph (1965), 1 Lincoln L. Rev. 39 , for this sad tale.

02 Louisell \& Willams, ante, n. 91, at 511. 
head surgeon the anaesthetist and the other doctors, however, were relieved of vicarious liability on the basis that they really could not control the conduct of the offending person in the circumstances. The hospital wriggled off the hook on the basis of state immunity in Minnesota. ${ }^{94}$

Because of difficulties that a plaintiff has in securing proof of what transpired during surgery, a court may invent devices to assist him. This may be another of the policy grounds that generated the "captain-ofthe-ship" doctrine. The case of Ybarra v. Spangard ${ }^{95}$ offers a remarkable technique to aid the patient who sues for negligence in the operating room in California. Relying on res ipsa loquitur, the court held that each person in the operating theatre would be held liable unless he proved that he was not individually responsible. No doubt this solution shatters the protection afforded medical personnel and hospitals by the "conspiracy of silence," and the immunity barrier, but at the same time it distorts the doctrine of res ipsa loquitur.

Perhaps a more preferable solution would be to hold the hospital liable for all operating room negligence, unless it is proven that the particular act was done by an independent doctor or under his orders. Since both doctors and hospital are normally insured, a successful claimant will not be defeated by evidentiary difficulties alone, and may have his judgment satisfied whoever is held liable. This technique places the obligation to control upon the hospital, where it can be most effectively exercised. If hospitals are made to bear the initial risk of loss, they may be encouraged to improve safety in the operating room by stricter regulation of operative procedures, by promulgating better rules and by their vigorous enforcement. The doctors, many of whom operate only infrequently, are in no position to supervise the operating room staff nor should they be required to do so. This does not mean that doctors should be blind to what goes on in the operating room; clearly they must keep alert for problems that arise, and may be held liable when they are aware of improper conduct. This solution may also avoid promiscuous actions against everyone who participated in the surgery, with the attendant time waste and damaging personal publicity to people often innocent of negligence. By permitting one action against the hospital, settlement of these cases may be increased because there will be an incentive for the hospital to discover the true facts and, if it wishes, it may sue the wrongdoer for indemnification. The primary responsibility is best granted to the hospital, therefore, because of its ability to regulate and its continuous control over its permanent staff. The recent developments in the case law appear to point in the direction of this development.

\section{CONCLUSION}

The law of hospital liability is undergoing a metamorphosis. As conditions in hospitals and operating rooms grow increasingly complex, old rubrics from a simpler age have yielded, albeit slowly, to newer, more realistic ones. The control test, which in earlier days precluded a patient from tort recovery against a hospital in professional liability cases has been

94 For a discussion of this case, see McCold. ante $n$. 90, at 602 . See also Salgo v. Stanford University (1957), 154 Cal. App. (2d) 560,317 P. (2d) 770 .

os (1944), 25 Cal. (2d) 496, 154 P.(2d) 687; See Prosser, Handbook on the Law of Torts (3d ed. 1964), at p. 227. 
exploded. The "captain-of-the-ship" doctrine which denied claimants recourse against their hospitals for operating theatre negligence has been largely abolished. In their stead, courts are utilizing new conceptions, like the direct duty to nurse, to promote results more consistent with modern attitudes and practices. Rather than assuming that the surgeon controls everyone in the operating theatre, courts are examining the actual control pattern in the operating room to determine who, if anyone, should bear vicarious responsibility. The policies of promoting safety, stricter hospital supervision of staff, avoidance of circuity of actions and damaging personal publicity and the need to compensate the victims have stimulated these developments in Canada and in England, where the nationalization of medical services as well spurred this development. It may well be that, ultimately, hospital litigation will be replaced by mandatory "hospital-accident" insurance, as suggested by Professor Ehrenzweig; ${ }^{96}$ in the meantime, however, it is comforting to observe that the common law has not stood idly by, but has begun to evolve its own novel weapons in response to changing societal conditions. 